\title{
PODSTAWOWE ZASADY TRANSPORTU I RUCHU WOJSK WLASNYCH I SOJUSZNICZYCH
}

W artykule omówiony zostat wojskowy transport sit sojuszniczych i sit wlasnych. Przedstawione zostaty podstawowe zasady $i$ reguly planowania przemieszczenia sił wojskowych. Scharakteryzowane zostało wsparcie sojusznicze Host Nation Support. Przybliżono czytelnikowi oznakowanie kolumn wojskowych, pojazdów regulacji ruchu oraz oznakowanie infrastruktury transportowej. Omówiono bezpieczeństwo ruchu wojskowych pojazdów.

\section{WSTĘP}

W dobie zagrożeń XXI wieku obserwujemy zwiększenie ilości przemieszczanego sprzętu wojskowego w ramach ćwiczeń, szkoleń lub pokazów sprzętu wojskowego. Ćwiczenia na szeroką skalę, które odbywają się na terenie Polski powodują że na nasze terytorium napływają duże ilości pojazdów mechanicznych wraz ze sprzętem, a także zwiększona liczba żołnierzy (rys.1). a)
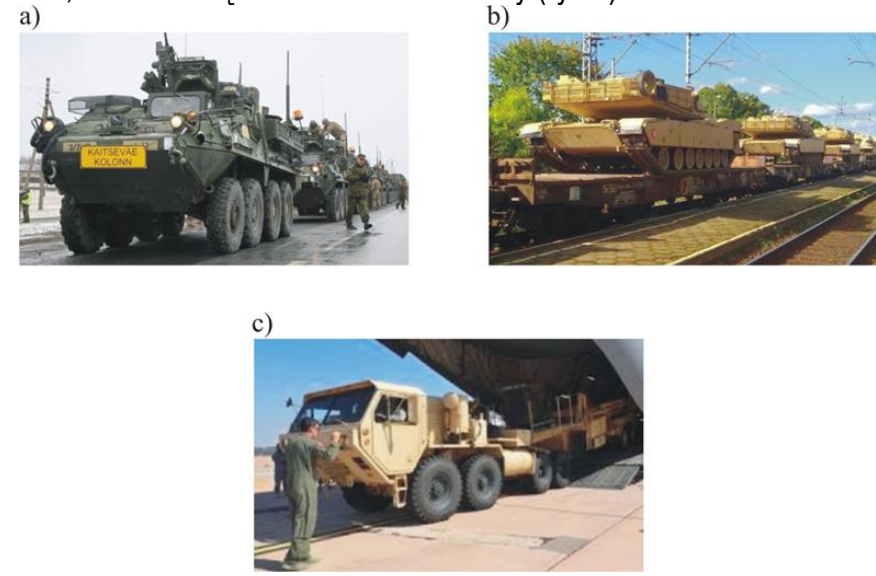

Rys. 1. Przykłady transportu sił sojuszniczych na terytorium RP: a) drogą - transportery opancerzone, b) koleją - czołgi, c) drogą powietrzną - pojazdy specjalne

Źródło: www.defence24.pl [20]

W związku z zagrożeniami nastapiły zmiany w systemie bezpieczeństwa narodowego. Wyznaczone zostały nowe zadania dla Sił Zbrojnych Rzeczypospolitej Polskiej. Posiadanie odpowiedniej infrastruktury transportowej przyczynia się w znacznym stopniu do wykonania tych zadań. Możliwości przemieszczania sił w celu podjęcia i wykonania zadań operacyjnych jest kluczowe dla zapewnienia efektywności przeprowadzenia przyszłych operacji narodowych i wielonarodowych.

Siły Zbrojne RP należące do Sojuszu Traktatu Północnoatlantyckiego NATO współdziałaja w realizacji wspólnej obrony oraz w operacjach reagowania kryzysowego. Udział w tych zadaniach zmusza więc do zachowania zdolności do przemieszczania sił wewnątrz i poza granicami kraju. Aby to osiagnąc konieczne jest osiagnięcie odpowiedniego standardu w zakresie transportu i ruchu wojsk zgodnie z przepisami obowiązującymi w NATO.

\section{PLANOWANIE PRZEMIESZCZENIA WOJSK}

Planowanie przemieszczania wojsk w różnego rodzaju operacjach powinno być zharmonizowane i realizowane w oparciu o opracowane procedury, uwzględniając przy tym cywilno-wojskowe zasoby wszystkich rodzajów gałęzi transportu. Jeżeli będzie to przemieszczenie na wielką skalę, wymaga to zgrania narodowych planów poszczególnych państw oraz planów NATO.

Doktryna Transportu i Ruchu Wojsk szczegółowo określa rolę, funkcje oraz zadania transportu i ruchu wojsk w czasie pokoju oraz w czasie zagrożenia z zewnątrz. Jej istotą jest przystosowanie przepisów krajowych do regulacji oraz standardów transportu i ruchu wojsk obowiazujących w Sojuszu NATO. System obronny $R P$ przygotowuje potencjał transportu i ruchu wojsk w ramach użycia w NATO, UE i ONZ. Realizacja tych zadań zmusza do racjonalnego wykorzystania wojskowych i cywilnych możliwości transportowych. NATO i inne zaangażowane państwa ponoszą wspólną odpowiedzialność za przemieszczenie sił zbrojnych biorących udział w operacji. Planowane przemieszczenia muszą być odpowiednio wcześniej zgłaszane przez państwo wysyłające do odpowiednich organów koordynujących ruch wojsk na obszarze danego kraju. Bez powiadamiania i uzgodnienia planowanego przemieszczenia wysyłanie wojsk jest niedopuszczone i zabronione. Siły zbrojne wojsk obcych nie moga pozostawać lub przemieszczać się przez terytorium innego państwa bez uzyskania zezwolenia tego państwa. W przypadku przemieszczeń międzynarodowych w planowaniu przemieszczenia należy uwzględnić czas na opracowanie uzgodnień międzynarodowych. Termin nie będzie przekraczał 30 dni i zależy od uwarunkowań administracyjnych państwa , przez które odbywa się przemieszczenie wojsk.

W planowaniu przemieszczenia ważna rzecza jest znajomość przez planistów zasad ruchu wojsk i ładunków przez obszar danego państwa oraz specyficznych warunków przewozu. Wymaga to, więc dużej staranności z uwzględnieniem przede wszystkim warunków przejazdu pojazdów nienormatywnych i przewozu towarów niebezpiecznych. Przemieszczenie wojsk obcych przez terytorium $R P$ droga lądową odbywa się zgodnie z zasadami międzynarodowymi wiążącymi $R P$ i państwo wysyłające oraz z uwzględnieniem przepisów prawa przewozowego, prawa o ruchu drogowym, przepisów celnych i granicznych oraz umowy ADR (fr. L'Accord européen relatif au transport international des marchandises Dangereuses par Route) - Umowa europejska dotycząca międzynarodowego przewozu drogowego towarów niebezpiecznych). Państwo, które 
zamierza przemieszczać swój personel i sprzęt techniczny musi uzyskać zgodę - zezwolenie państwa, przez które będzie się przemieszczało lub na którym będzie pozostawało.

W przypadku pobytu wojsk obcych na terytorium $R P$ zgodę wydaje:

1. Minister Obrony Narodowej - na okres pobytu do 3 miesięcy dla wojsk państw sojuszniczych NATO i dla wojsk innych państw, gdy liczebność ich nie przekracza tysiąca osób, a pobyt ma na celu udział w szkoleniu wojskowym,

2. Rada Ministrów na czas określony - w pozostałych przypadkach.

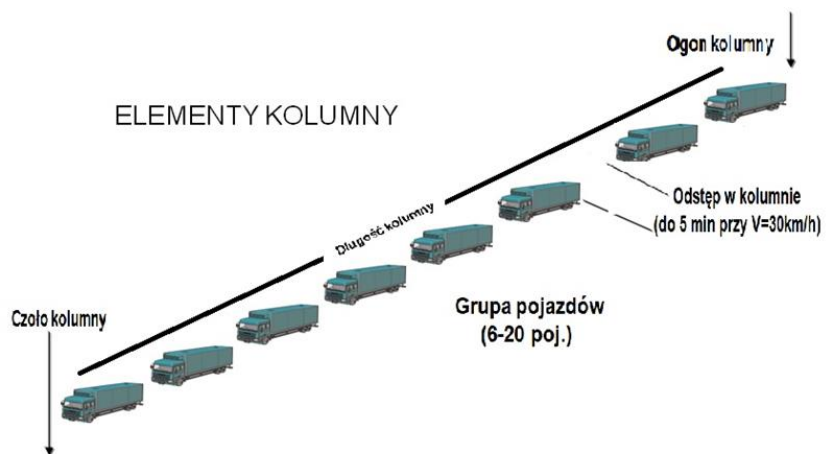

Rys. 2. Schemat kolumny wojskowej składającej się z grup pojazdów SZ RP

Źródło: Zasady Wojskowego Ruchu Drogowego [1]

W Siłach Zbrojnych RP powołane są komórki organizacyjne, które zajmuja się organizacją transportu i ruchu wojsk. Ich zadaniem jest zapewnienie szybkiego przemieszczenia wydzielonych sił na i poza terytorium Polski. Takie same zadanie będa miały siły Paktu NATO w ramach sojuszu. W związku z tym tworzone są rozwiazzania organizacyjne do udzielenia wsparcia wojskom sojuszniczym oraz wojskom własnym dotyczące przemieszczania sił, transportów z zaopatrzeniem lub pozyskiwania środków transportowych do przemieszczenia. Należy, więc w ramach zobowiązań sojuszniczych współdziałać, a także zachować elastyczność w planowaniu transportu i ruchu wojsk oraz podczas reagowania na zmiany sytuacji operacyjnej.

Za całokształt przedsięwzięć organizacyjno-technicznych zwiazanych z przewozem i ruchem wojsk, przygotowaniem i osłona techniczną sieci transportowej, a także pracami załadowczowyładowczymi odpowiada podsystem transportu i ruchu wojsk (TiRW). Celem podsystemu jest pozyskanie środków transportowych, przygotowanie infrastruktury transportowej, jednostek wykonawczych, oraz opracowanie procedur zabezpieczenia transportu i ruchu wojsk.

\section{PODSTAWOWE REGUKY PRZEMIESZCZENIA WOJSK}

Zapewnienie sprawnego przemieszczania wojsk jest podstawa osiagnięcia sukcesu w przeprowadzanej operacji. NATO i inne państwa zaangażowane ponoszą wspólną odpowiedzialność za przemieszczanie i ruch wojsk - sił zbrojnych biorących udział we wspólnej operacji.

Podstawową reguła przemieszczania wojsk jest:

1. Uzyskanie zgody Państwa Wysyłającego na przemieszczenie i pobyt wojsk na terytorium $R P$.

2. Akceptacja planu przemieszczania przez STiRW-CKRW (Szefostwo Transportu i Ruchu Wojsk - Centrum Kierowania Ruchem Wojsk).
3. Przedstawienie na granicy stosownych dokumentów dla Straży Granicznej i Służby Celnej.

4. Przekraczanie granic państwowych w umundurowaniu.

5. W przypadku przewożenia broni - posiadanie zezwolenia.

6. Uzyskanie zezwolenia wojskowego na przewóz towarów niebezpiecznych, pojazdów nienormatywnych i kolumn pojazdów wojskowych.

7. Stosowanie na terytorium $R P$ przepisów obejmujących Siły Zbrojne RP.

Główna rolę w przemieszczeniu sił i środków jest odpowiednie zaplanowanie przebiegu transportu od punktu rozpoczęcia do punktu zakończenia zgodnie z „Planem przemieszczenia” (rys.3). W tym celu ustala się zasady organizacji przemieszczania pojazdów wojskowych z zarządcami dróg, Strażą Graniczną, Żandarmerią Wojskową, Policją oraz Służbą Celną. W przypadku przemieszczeń międzynarodowych następują ustalenia ministerialne.

Ważnym więc elementem w planowaniu przemieszczenia jest infrastruktura drogowa i sieć drogowa. Klasyfikacja dróg pozwala organom zajmującym się organizacją transportu i ruchu na pozyskanie charakterystyki sieci drogowej. Pod uwagę należy wziąć:

- szerokość drogi,

- typ drogi,

- wojskową klasyfikację dopuszczalnego obciążenia dróg,

- prześwit.

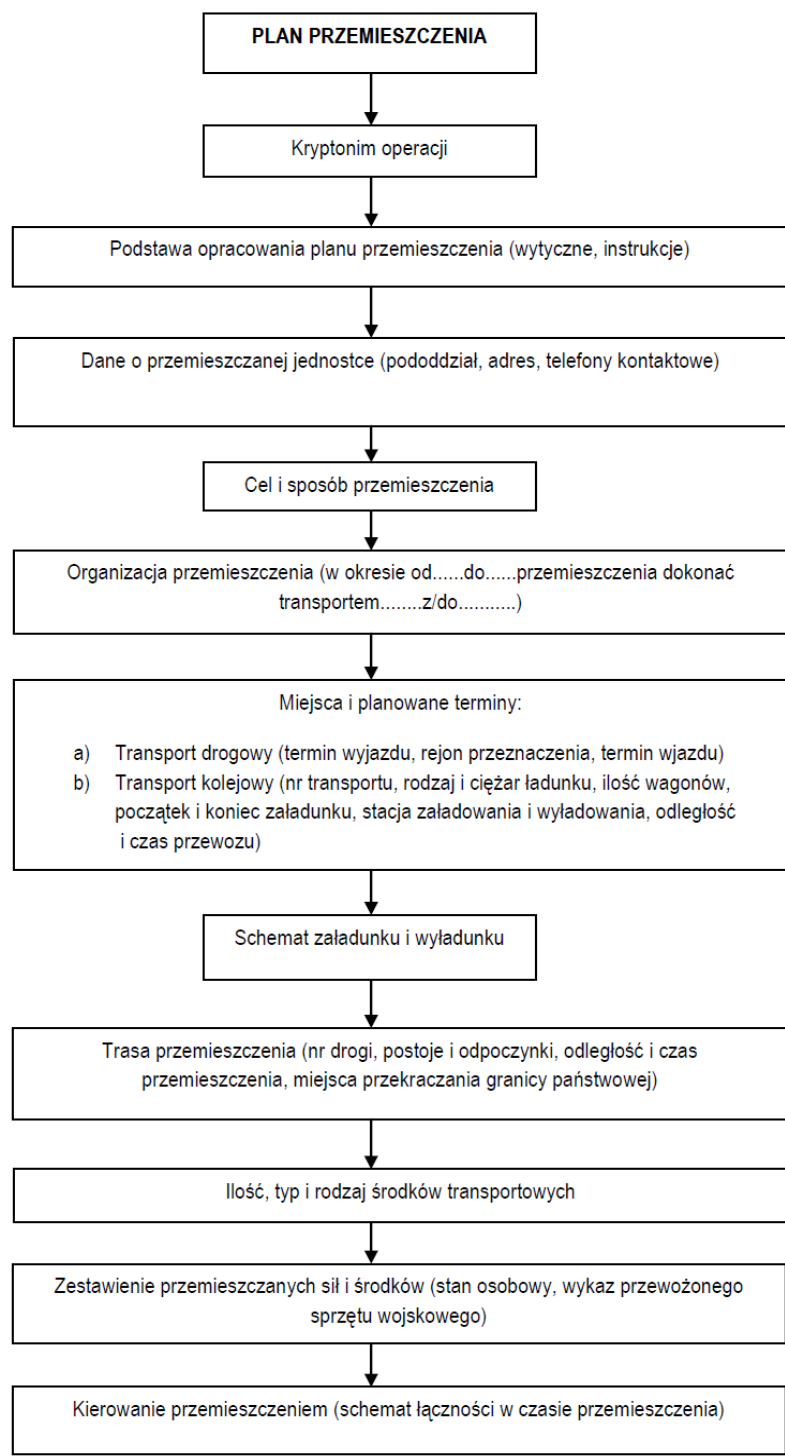

Rys. 3. Plan przemieszczenia jednostki wojskowej Źródło: opracowanie własne 
Przejazd będzie się odbywał z wykorzystaniem sieci podstawowych tras cywilnych i tras wojskowych. Przed przyjęciem wojsk sojuszniczych na terytorium $R P$ ważną rolę odgrywaja przeprowadzane konferencje planistyczne z przedstawicielami państw przybywających. Celem tych konferencji jest omówienie oraz zapoznanie $z$ infrastrukturą logistyczną na terenie Polski, możliwościami logistycznymi w celu zagwarantowania pobytu na terytorium RP oraz z procedurami i przepisami krajowymi. llość przeprowadzanych konferencji zależy od potrzeby uzgodnień w danych tematach.

W planowaniu przemieszczenia sporządza się plany przewozów w zależności od wykorzystanej gałęzi transportu oraz wyznacza się miejsca przekraczania granicy państwowej.

W przypadku przekraczania granicy państwa na drogowych przejściach granicznych i kolejowych oraz w miejscach przyjęcia sprzętu i ludzi, a mianowicie na lotniskach i w portach morskich, można spotkać przedstawicieli wojsk sojuszniczych odpowiedzialnych za dalsze przemieszczenie wojsk. W takim przypadku wyznacza się Grupę Kontroli Ruchu z Wojskowej Komendy Transportu, której przedstawiciel koordynuje przyjęcie i dalszy ruch wojsk oraz przekazuje informacje o organizacji przebiegu odprawy i zasadach pobytu wojsk, które obowiazują na terytorium kraju.

Specyfika przekraczania granicy państwowej w ruchu drogowym i kolejowym jest zbliżona z tą różnica, że przekroczenie granicy przez Kolejowe Punkty Graniczne wymaga dodatkowo przekazania pomiędzy przewoźnikami listów przewozowych, które są podstawą do wzajemnych rozliczeń finansowych.

Załadunki i wyładunki sprzętu wojskowego w portach morskich, czy w portach lotniczych, koordynowane sa przez przedstawiciela Wojskowej Komendy Transportu w porozumieniu z dyrekcja danego portu i przedstawicielem jednostki wojskowej przemieszczanej.

Bardzo ważne w porcie morskim oraz lotniczym jest wyznaczenie stref przyjęcia, składowania oraz załadunku i wyładunku sprzętu. Dodatkowo do zadań osób funkcyjnych w trakcie za i wyładunku należy uzgadnianie i organizowanie z właściwymi terytorialnie organami celnymi i straży granicznej terminów przeprowadzania odpraw celnych i granicznych oraz prowadzenie ewidencji środków materiałowych zgromadzonych w porcie, a także załadowanego na środki transportu. W porcie lotniczym należy wyznaczyć właściwe strefy oraz system załadunku i wyładunku bagaży głównych i ładunku cargo (rys.4). Dodatkowo należy poinformować przedstawiciela wojsk sojuszniczych o zasadach bezpieczeństwa ruchu pojazdów wojskowych na terenie lotniska.

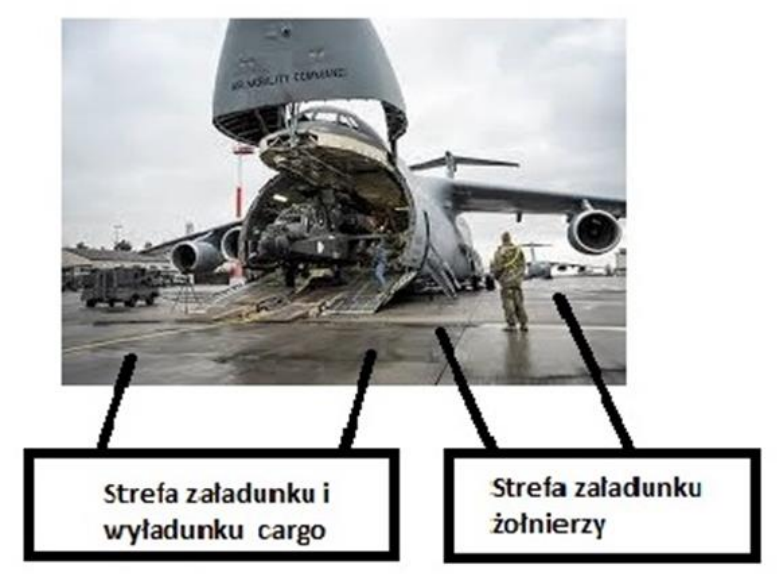

Rys.4. Strefa załadunku i wyładunku cargo w wojskowym porcie lotniczym

Źródło: www.army.mil [21]
Generalnie przemieszczanie oraz za i wyładunek w danych rodzajach gałęzi transportu musi przebiegać sprawnie. Bez przeprowadzonych uzgodnień i koordynacji podpisanych umów sprawność systemu transportowego może zostać zagrożona i zachwiana, co w konsekwencji doprowadzi do opóźnień przemieszczanego sprzętu wojskowego (kolumn, pojazdów itd.).

W układzie sojuszniczym główną rolę na terenie $R P$ spełnia na szczeblu centralnym - STiRW-CKRW w połączeniu z jednostkami wykonawczymi, jakimi są Wojskowe Komendy Transportu (WKTr). Zadaniami STiRW - CKRW jest wiec; planowanie i przemieszczanie wojsk własnych i sojuszniczych na obszarze kraju, przemieszczanie wydzielonych kontyngentów poza granicami kraju, planowanie przygotowania infrastruktury transportowej kraju w sprawach zwiazanych z obronnością oraz dla wojsk sojuszniczych, pełnienie funkcji gestora sprzętu przeładunkowego, zabezpieczenia ruchu wojsk.

\section{WSPARCIE SOJUSZNICZE HNS}

Istotną rolę w strukturach transportu i ruchu wojsk odgrywaja Wydziały i Oddziały Transportu i Ruchu Wojsk oraz HNS (ang. HOST NATION SUPPORT) na poszczególnych szczeblach organizacyjnych. HNS to cywilna i wojskowa pomoc udzielana przez państwo gospodarza w czasie pokoju, kryzysu i w czasie wojny sojuszniczym siłom zbrojnym i organizacjom, które są rozmieszczane, wykonuja zadanie lub przemieszczaja się przez terytorium państwa gospodarza. Podstawę do udzielania takiej pomocy stanowia porozumienia, zawarte pomiędzy stosownymi władzami państwa gospodarza i państw wysyłających oraz/lub NATO.

HNS są to komórki wewnętrzne Regionalnych Baz Logistycznych (RBLog), które również odpowiedzialne są za planowanie i kierowanie ruchem wojsk i zabezpieczeniem przemieszczenia wojsk własnych i sojuszniczych na obszarze odpowiedzialności RBLog w czasie pokoju, kryzysu oraz wojny. Komórka ta pełni rolę „państwa - gospodarza” związaną z zabezpieczeniem przewozów wojskowych oraz organizowaniem prac przeładunkowych na obszarze odpowiedzialności RBLog. HNS pełni funkcje punktu kontaktowego RBLog w zakresie realizacji zadań HNS.

Jednostkami wykonawczymi są WKTr, które to współdziałaja z terenowa, cywilna administracją drogowa, kolejowa, żeglugi śródlądowej, portów morskich i portów lotniczych. Główne ich zadanie to wyznaczanie oraz uzgadnianie z administracją cywilną warunków przejazdów kolumn wojskowych i pojazdów ponadnormatywnych oraz pojazdów z towarami niebezpiecznymi. Jednostka ta przygotowuje i wydaje stosowne pozwolenia na przejazd drogowy. Bierze również czynny udział w przyjęciu sił sojuszniczych w punktach granicznych, w portach i na lotniskach, a także koordynuje przemieszczanie tych wojsk do planowanych rejonów ćwiczeń i poligonów. Zapewnia przy tym ich bezkolizyjny ruch. Elementem mobilnym i wykonawczym jest regulacja ruchu, która przeprowadza pilotaże kolumn, pojazdów nienormatywnych oraz pojazdów z materiałami niebezpiecznymi.

Jednostka ta posiada wyposażenie, które zagwarantuje pełną kontrole regulacji ruchu oraz umożliwi kontrole stanu dróg.

Wszystkie wymienione elementy biora czynny udział w bezpiecznym i sprawnym przemieszczeniu wojsk własnych i wojsk sojuszniczych. Ich działanie przyczynia się do tego, że zadania transportowe sa wykonane na czas.

Ruch transportów wojskowych (kolumn pojazdów, pojazdów ponadnormatywnych, pojazdów przewożących towary niebezpieczne) przez terytorium RP podlega ciagłemu nadzorowaniu, monitoringowi i koordynacji przez odpowiednie do tego powołane krajowe organy transportowe i służby dyżurne (dyspozytorskie) wojskowe i cywilne. Organy te czuwają nad bezpieczeństwem i podejmuja 
stosowne decyzje do wstrzymania przemieszczenia kolumn (pojazdów) włącznie.

Dużą rolę w planowaniu przewozów transportem drogowym odgrywa wydawanie pozwoleń na przejazd dla kolumn wojskowych, pojazdów nienormatywnych i przewożących towary niebezpieczne. Zezwolenie na przejazd drogowy wydaje się na jednorazowy przejazd. W obecnych czasach obserwuje się wzrost ilości kolumn wojskowych oraz pojazdów przewożących towary niebezpieczne i pojazdów nienormatywnych.

Z definicji „kolumna pojazdów” [1] jest to grupa przemieszczających się pojazdów, dowodzona przez dowódcę kolumny, po tej samej trasie, w tym samym czasie i w tym samym kierunku. Kolumna może składać się z określonej ilości zorganizowanych elementów, które moga być zwane grupami pojazdów, konwojami lub pakietami.

W okresie pokoju pojedyncza grupa pojazdów (lub samodzielna kolumna) składa się, z co najmniej sześciu i maksymalnie dwudziestu pojazdów. Ograniczeń tego typu nie stosuje się w razie przejazdu kolumny pojazdów w związku z działaniami mającymi na celu zapewnienie bezpieczeństwa i porządku publicznego oraz w przypadku realizacji zadań związanych z obronnością państwa. Między pojazdami ustala się odległości wynoszące od $50 \div 100 \mathrm{~m}$, jednak w uzasadnionych sytuacjach może nastapić zwiększenie odległości między grupami pojazdów, które określą dowódcy kolumn. Minimalna ilość pojazdów w kolumnie to dwa pojazdy.

\section{ZASADY FORMALNE PRZEMIESZCZENIA WOJSK}

W świetle obowiazujących przepisów krajowych [3] jednostki wojskowe będące na terytorium Polski i wykonujące zadania przewozowe powinny mieć zgodę na pobyt oraz pozwolenie na przejazd. Dotyczy to również wojsk RP. Pozwolenie na przejazd drogowy wymagane jest w następujących przypadkach przejazdów dla [1]:

a) pojazdów nienormatywnych,

b) pojazdów przewożących towary niebezpieczne,

c) kolumn pojazdów w składzie 6 pojazdów i więcej.

Podstawa do otrzymania takiego pozwolenia na przejazd jest złożenie zapotrzebowania $w$ terminach $w$ zależności od rodzaju przemieszczenia na terytorium kraju lub w związu z przejazdem międzynarodowym. Każdy przejazd kolumny wojsk na terenie RP w składzie sześć i więcej pojazdów, przewóz towarów niebezpiecznych oraz przejazd pojazdów nienormatywnych, na które uzyskano i wydano pozwolenie, jest zgłaszany przez właściwe komórki transportu i ruchu wojsk organom Żandarmerii Wojskowej. W przypadku realizacji przemieszczeń międzynarodowych na terenie $R P$, pilotowanie kolumn z towarami niebezpiecznymi oraz innych kolumn, które podlegaja ochronie, są przejmowane na granicy państwa przez ŻW i pilotowane do punktu przeznaczenia lub do punktu, w którym odbywa się przekazanie odpowiedzialności.

Aby zapewnić bezpieczny i sprawny przejazd przez tereny zabudowane, należy dążyć do rozwiazań systemowych, które spowodują zmniejszenie zakłóceń w ruchu cywilnym. Zdarza się często, że kolumna blokuje ruch drogowy. Zwiazzane to jest przede wszystkim z tym, że kolumna musi poruszać się z ograniczoną prędkością, ale zdarza się również często to, że kierowcy wojskowi nie utrzymują odpowiedniego dystansu przed pojazdem i przez to następuje rozciagniecie kolumn. Należy podkreślić, że według przepisów wjeżdżanie pojazdów cywilnych w kolumny wojskowe jest naruszeniem prawa, a wyprzedzanie kolumny należy wykonać jednym manewrem [2]. Pojedyncze pojazdy moga wyprzedzać kolumny podczas ich postojów lub, gdy istnieje między nimi duża różnica prędkości. Pojazdy moga wyprzedzać jedynie kolumnę, gdy manewr ten będzie bezpieczny. Kolumny moga wyprzedzać inne kolumny dopiero po otrzymaniu zgody od upoważnionych władz kontroli ruchu. Manewr wyprzedzania musi być nadzorowany przez personel regulacji ruchu. W celu zapewnienia bezpieczeństwa na drodze, należy uruchamiać grupy pojazdów w ilości od 6 do 20 pojazdów.

Ważną rzeczą jest znajomość przepisów krajowych dotyczacych ruchu drogowego. Kierowcy wojsk sojuszniczych prowadzący wojskowe pojazdy nie znają naszych krajowych przepisów, a dodatkowo łamią te przepisy, np. nie zatrzymując się na czerwonym świetle lub poruszają się z nadmierną prędkością. Przepisy ruchu drogowego muszą obowiazywać również kierowców wojskowych z innych państw. Kierowcy cały czas podlegaja przepisom ruchu drogowego państwa, na terenie, którego przebywają i prowadzą pojazd [3]. Dotyczy to również przestrzegania znaków drogowych, ograniczeń prędkości, ruchu przez mosty itd. Takie poczynania związane z nieprzestrzeganiem przepisów krajowych moga spowodować katastrofę w ruchu drogowym, a zauważamy to już coraz częściej na naszych drogach z udziałem pojazdów wojsk sojuszniczych.

W celu poprawy bezpieczeństwa w czasie przejazdów, do pilotażu kolumn wysyła się elementy mobilne w postaci ŻW, regulacji ruchu lub policji, które pełnią rolę pilota (rys.5). Jest to bardzo dobre rozwiązanie z uwagi na fakt, że liczba kolumn poruszająca się po naszych drogach zwiększa się z roku na rok.

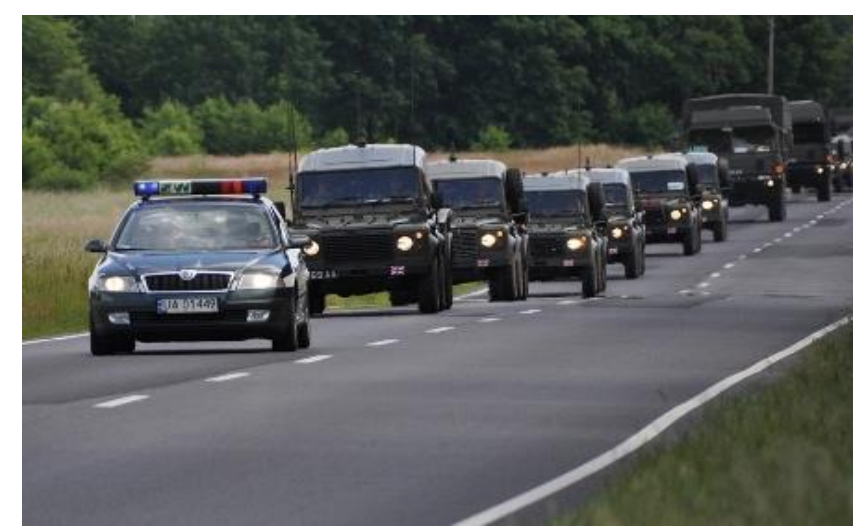

Rys.5. Pilotowanie kolumny pojazdów

Źródło: zw.wp.mil.pl [22]

Na podstawie przepisów [1] pilotowaniu po drogach publicznych podlegaja pojazdy $S Z R P$, których wymiary geometryczne przekraczają co najmniej jedną z wielkości takich jak:

a) długość pojazdu - $23 \mathrm{~m}$,

b) szerokość pojazdu-3,2 m,

c) wysokość pojazdu $-4,5 \mathrm{~m}$,

Jeden pojazd pilotujacy stosowany jest w przypadku, gdy wymiary geometryczne pojazdu SZ RP przekraczają co najmniej jedną z wielkości:

a) długość pojazdu - $28 \mathrm{~m}$,

b) szerokość pojazdu-3,6 m,

c) wysokość pojazdu - 4,7 m,

d) rzeczywista masa całkowita pojazdu - powyżej $60 \mathrm{t}$.

Natomiast dwa pojazdy pilotujące poruszające się z przodu i z tyłu pojazdu stosuje się w przypadku, gdy pilotowana ma być kolumna lub grupa pojazdów nienormatywnych oraz w przypadku pojazd gasienicowego z wyjątkiem pojazdu na gassienicach gumowych. Dwa pojazdy pilotujące stosuje się także w odniesieniu do pojazdu wyposażonego tylko w jedno światło drogowe lub mijania, w światło obrysowe lub odblaskowe, niebędace pojazdem jednośladowym, poruszajacy się w warunkach niedostatecznej widoczności. 
O konieczności pilotowania organ wydający zezwolenie wojskowe powiadamia w terminie nie krótszym niż 5 dni przed planowanym rozpoczęciem przejazdu:

1. Komendanta Oddziału ŻW właściwego ze względu na miejsce rozpoczęcia pilotowania, gdy trasa przejazdu przebiega tylko przez obszar jego właściwości, za pośrednictwem środków komunikacji elektronicznej,

2. Komendanta Głównego ŻW , gdy trasa przejazdu przebiega przez obszary właściwości, co najmniej dwóch oddziałów Żandarmerii Wojskowej, za pośrednictwem środków komunikacji elektronicznej,

3. właściwych dowódców, którym podlegają pododdziały regulacji ruchu, w formie pisemnej lub za pośrednictwem środków komunikacji elektronicznej.

Informacje o pilotowaniu umieszcza się w zezwoleniu wojskowym.

\section{OZNAKOWANIE KOLUMN WOJSKOWYCH ORAZ POJAZDÓW REGULACJI RUCHU}

Bardzo ważnym zagadnieniem w przemieszczaniu się kolumn pojazdów wojskowych jest ich prawidłowe oznakowanie (rys. $6,7,8,9)$. Każda kolumna, której przydzielono zezwolenie na marsz będzie, więc miała nadany numer zwany "numerem zezwolenia na marsz". Numer ten będzie identyfikował kolumnę podczas całego przemieszczenia, również przy przekraczaniu granicy państwa. Numer taki musi być naniesiony i wykonany odblaskowym kolorem w stosunku do koloru pojazdu i musi być umieszczony po dwóch stronach każdego pojazdu oraz być czytelny z ziemi i podczas zmian pogody. Wokresie pokoju, światła wszystkich pojazdów poruszających się w kolumnie muszą być włączone (światła mijania).

1. Pierwszy pojazd każdego elementu kolumny musi mieć zamontowaną pomarańczową tablicę oznaczająca kolumnę oraz niebieską flagę zamocowaną z przodu po lewej jego stronie.
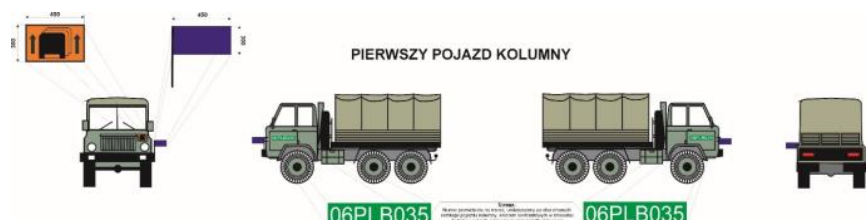

Rys. 6. Sposób oznakowania pierwszego pojazdu kolumny wojskowej

Źródło: Zasady Wojskowego Ruchu Drogowego [1]

2. Ostatni pojazd każdego elementu kolumny musi mieć zamontowaną pomarańczową tablicę oznaczającą kolumnę oraz zieloną flage zamocowaną z przodu, po lewej jego stronie.
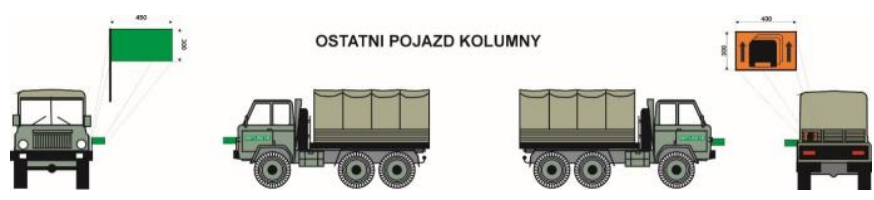

Rys. 7. Sposób oznakowania ostatniego pojazdu kolumny wojskowej

Źródło: Zasady Wojskowego Ruchu Drogowego [1]

3. Dowódca kolumny powinien być oznakowany czarno biała flaga z przodu, po lewej stronie pojazdu.
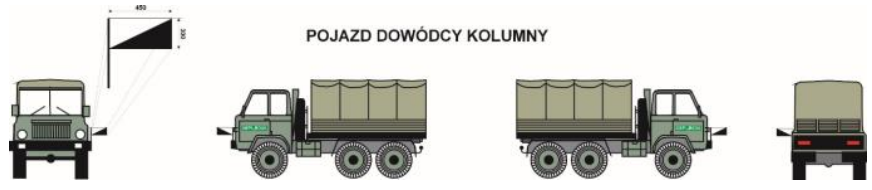

Rys. 8. Sposób oznakowania pojazdu dowódcy kolumny wojskowej Źródło: Zasady Wojskowego Ruchu Drogowego [1]

4. Kierowca uszkodzonego pojazdu musi usunać flagę, (jeśli ma zamocowana), i jeśli potrzebuje pomocy technicznej, musi zamocować flagę żółta, tak, aby była widoczna dla nadjeżdżajacych pojazdów.

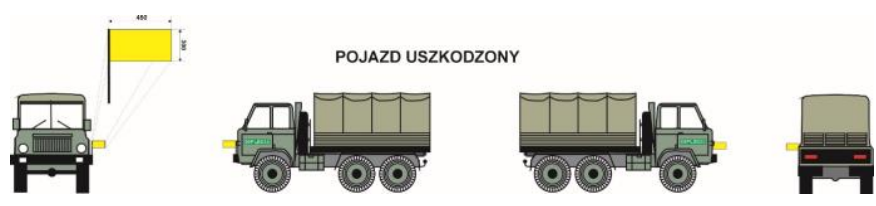

Rys. 9. Sposób oznakowania uszkodzonego pojazdu kolumny wojskowej

Źródło: Zasady Wojskowego Ruchu Drogowego [1]

Obserwując ruch na drogach możemy również dostrzec pojazdy regulacji ruchu oznakowane np. ŻW lub Regulacja Ruchu, a także pojazdy sanitarne i pojazdy przeznaczone do transportu niewybuchów.

Oznakowanie ich przedstawia się przykładowo w postaci (rys.10):

1. Oznakowanie pojazdów pododdziałów regulacji ruchu:

- biały pas z napisem REGULACJA RUCHU oraz litera $R$ umieszczona w rąbie na drzwiach,

- symbolem służby transportu i ruchu wojsk umieszczonym za przednia szyba,

- sygnalizacją świetlną, niebiesko - czerwona, na dachu pojazdu.

2. Pojazdy Żandarmerii Wojskowej mają być oznakowane jako pojazdy uprzywilejowane, z przodu i z tyłu, znakami konwencjonalnymi żanadarmerii wojskowej.

3. Pojazdy Sanitarne, ambulanse oraz inne pojazdy użytkowane wyłącznie w celach medycznych, mają być oznakowane zgodnie z zasadami Konwencji Genewskiej. Takimi znakami są jeden Czerwony Krzyż lub Czerwony Półksiężyc na białym tle, o kształcie kwadratu lub koła, namalowane na:
a. poszyciach bocznych pojazdu,
b. dachu pojazdu,
c. dachu kabiny kierowcy,
d. drzwiach tylnych lub poszyciu tylnym.

4. Pojazdy do transportu niewybuchów. Pojazdy jednostek do przewozu materiałów wybuchowych i niewypałów znakowane są napisem Patrol Saperski.

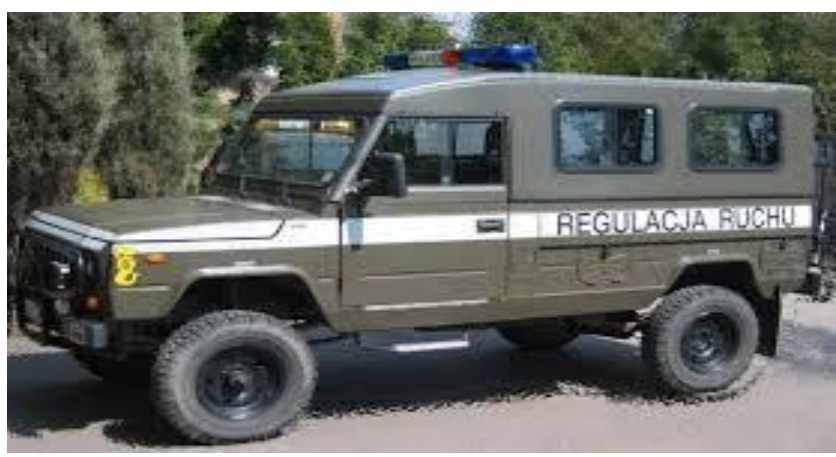

Rys.10. Pojazd pilotujący pododdziału regulacji ruchu Źródło: federal.pl [23]

\section{AUTOBUSY 6/2018}


Pojazd pilotujący powinien wysyłać sygnały świetlne w kolorze niebieskim, a w przypadku pilotowania kolumny pojazdów dodatkowo błyskowe sygnały świetlne w kolorze czerwonym.

\section{OZNAKOWANIE INFRASTRUKTURY TRANSPORTOWEJ}

Innym rodzajem oznakowania pojawiającym się w naszym otoczeniu jest oznakowanie dotyczące klasyfikacji mostów - klasyfikacja MLC. Oznakowanie takie pojawia się w ramach odbywajacych się w naszym kraju ćwiczeń sojuszniczych lub ćwiczeń narodowych wojsk (rys.11). Wojskowa klasyfikacja obciazżenia - znormalizowany system, w którym drogi, mosty czy promy są odpowiednio oznaczone według klas dopuszczalnego obciążenia; pojazdy również oznacza się według minimalnej klasy drogi, mostu czy promu, po których mogą się poruszać. Oznakowanie pojazdów i obiektów mostowych według umów standaryzacyjnych NATO polega na nadaniu każdemu pojazdowi kołowemu i gasienicowemu oraz obiektom mostowym numeru klasyfikacyjnego obciążenia wojskowego, a następnie na ustawieniu znaków z tymi numerami przed obiektami mostowymi oraz wymalowaniu ich na pojazdach wojskowych.

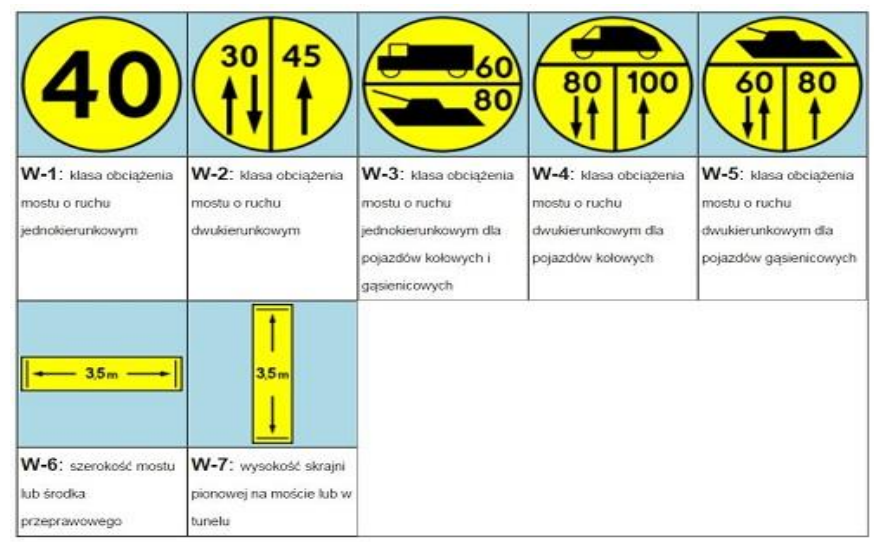

Rys.11. Oznaczenie infrastruktury (droga, most) wg. minimalnej klasy drogi, mostu.

Źródło: info-car.pl [24]

MLC jest to numer klasy odpowiadający bezpiecznemu obciażeniu obiektu mostowego, wskazujący na maksymalną klasę pojazdów, które w normalnych warunkach mogą poruszać się po obiekcie mostowym, drodze. Maksymalne klasy pojazdów, które mogą bezpiecznie korzystać z drogi zwykle odpowiadają najniższej klasie obciążenia obiektu mostowego na tej drodze.

Wojskowy numer klasyfikacyjny jest tylko numerem, nie odpowiada on masie pojazdu. Jeżeli numer klasy pojazdu jest mniejszy lub równy numerowi klasy mostu, promu, drogi, to pojazd może przejechać przy zachowaniu względów bezpieczeństwa. Przykładowe oznaczenie obiektu infrastruktury drogowej przedstawia rys.12.

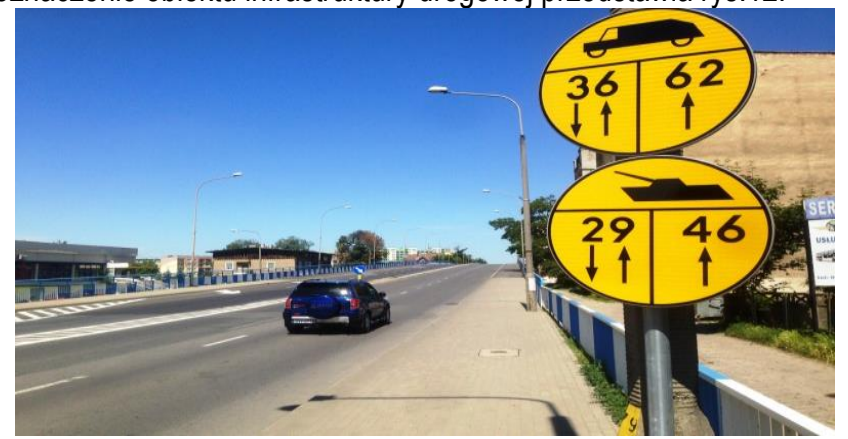

Rys.12. Przykładowe oznaczenie obiektu infrastruktury drogowej Źródło: gddkia.gov.pl [25]

\section{BEZPIECZENSTWO RUCHU POJAZDÓW SIŁ ZBROJNYCH RP.}

W celu doskonalenia bezpieczeństwa poruszania się po drogach publicznych w Siłach Zbrojnych na bieżąco przeprowadzane są instruktaże z kierowcami oraz szkolenia profilaktyczne z przedstawicielami Żandarmerii Wojskowej na tematy bezpieczeństwa w ruchu drogowym oraz sposoby ograniczania występujących zagrożeń. Dodatkowo przekazywane sa również dla kierowców informatory i instrukcje dotyczące bezpiecznego poruszania się kolumn w ruchu drogowym.

W praktyce mamy do czynienia z dużą ilością pojazdów, które jada jeden za drugim w odległości wielokrotnie mniejszej niż dozwolonej w przepisach. Stan zagrożenia następuje w chwili hamowania i w konsekwencji zmiany odległości bezpiecznej miedzy pojazdami w kolumnie. Zmiany parametrów ruchu kolumny następują również w związku z przyspieszeniami pojazdu poprzedzającego i nadążajacego (w celu zachowania ciagłości kolumny).

Raport Krajowej Rady Bezpieczeństwa Ruchu Drogowego [18] w zakresie stanu bezpieczeństwa w ruchu drogowym, wskazuje na podstawie danych z 2015r. na istotne problemy w oszacowaniu przez kierującego bezpiecznej odległości pomiędzy pojazdami oraz doboru prędkości gwarantującej bezpieczeństwo w czasie ruchu kolumny. Ilości wypadków drogowych oraz okoliczności ich powstania w 2015 roku przedstawia rys.13 i 14.

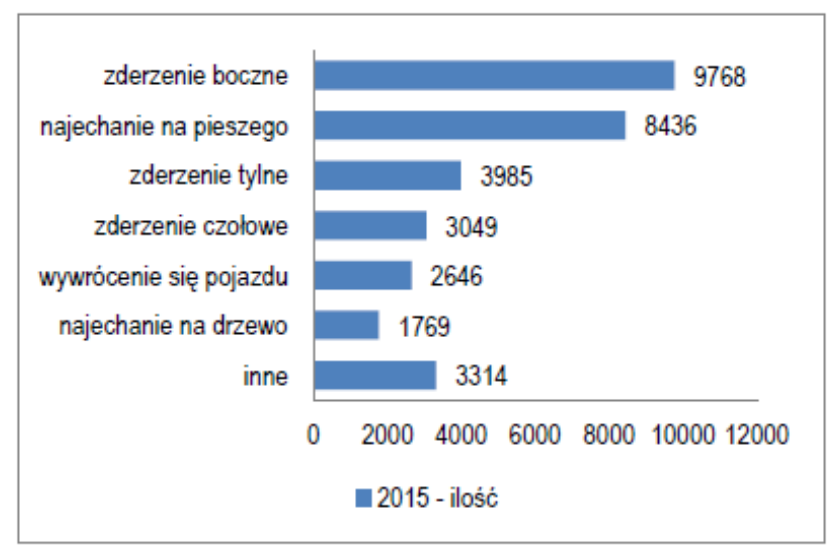

Rys.13. llość wypadków drogowych w 2015 r.

Źródło: kbrrd.gov.pl [18]

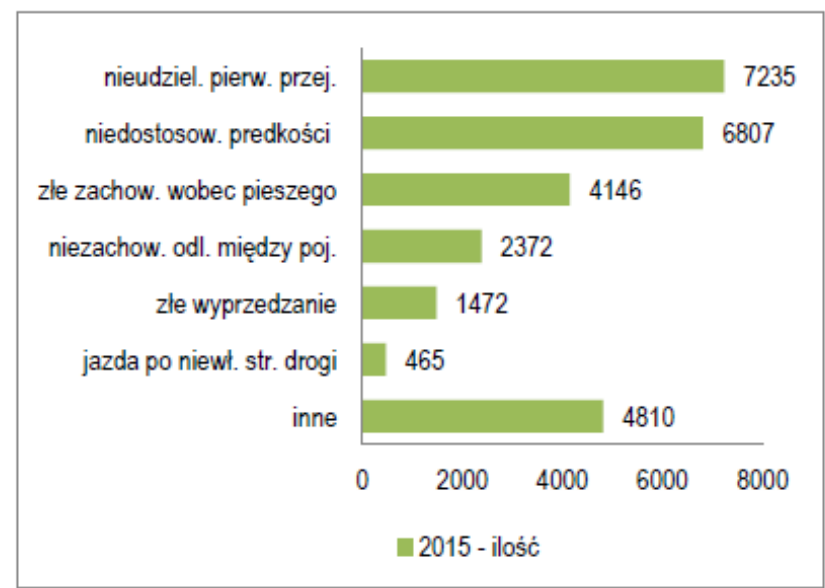

Rys.14. Okoliczności powstania wypadków drogowych w 2015 r. Źródło: kbrrd.gov.pl [18]

Zderzenia tylne zajmuja trzecie miejsce pod względem ilości wypadków. W 2015 roku w Polsce odnotowano 3985 tego rodzaju 
zdarzeń w ruchu drogowym, w których śmierć poniosło 211 osób. Dane statystyczne wskazuja, że nastapił również wzrost ilości wypadków spowodowanych niezachowaniem bezpiecznego odstępu pomiędzy pojazdami ( 2372 wypadki), w których śmierć poniosło 49 osób. Według danych Komendy Głównej Policji [19] w roku 2015 miało miejsce 27307 wypadków z winy kierujących pojazdami, których głównymi przyczynami było: nieprzestrzeganie pierwszeństwa przejazdu (7235 wypadków), niedostosowanie prędkości do warunków ruchu (6807 wypadków). Z analiz wynika, ze większość wypadków powstaje również w związku z przekraczaniem prędkości jazdy. Rozpatrując transporty wojskowe, \% wypadków z udziałem pojazdów wojskowych jest na poziomie $0,5 \%$. Biorąc pod uwage dane statystyczne dotyczące błędów kierujących w zakresie oszacowania bezpiecznej odległości miedzy pojazdami oraz przekraczanie prędkości dopuszczalnej, stanowi to istotny problem w zachowaniu i kształtowaniu bezpieczeństwa w ruchu drogowym.

\section{PODSUMOWANIE}

Coraz więcej tragicznych doniesień można zaobserwować w mediach, związanych z udziałem wojskowych pojazdów. Aby zmniejszyć niebezpieczeństwo związane z transportem należy rozpocząc szerszą edukację, prowadzić szkolenia z kierowcami, przeprowadzać terminowe instruktaże przed wyjazdami, a także w sytuacji popełnienia wykroczenia, wyciagać wnioski dyscyplinarne, pozbawiając kierowców prawa jazdy na określony czas. W przypadku kierowców państw sojuszniczych należy wzmocnić kontrolę drogową tych pojazdów i reagować na naruszenia przepisów krajowych. Na konferencjach planistycznych zaznajamiać z przepisami krajowymi i respektować ich wykonywanie. Działanie elementów regulacji ruchu w postaci ŻW, Policji i jednostek regulacji ruchu powinno przyczyniać się do zakazu wjazdów na kontrolowane trasy, do których jest wymagane zezwolenie na przejazd drogowy dla każdego pojazdu lub kolumny nieposiadajacego takiego zezwolenia. Jednostki te powinny również podejmować stosowne działania w celu zapobiegania i zmniejszania zatłoczenia poprzez odpowiednie blokowanie skrzyżowań $w$ trakcie przemarszu kolumny wojskowej. Reasumując, duży ruch kolumn wojskowych na naszych drogach sprawia, że występuje coraz więcej kolizji z udziałem pojazdów wojskowych.

Prawidłowe zaplanowanie oraz organizacja przemieszczenia wojsk wpływa na bezpieczeństwo przejazdów kolumn wojskowych. $W$ realizacji tego zadania biora udział organy transportu i ruchu wojsk tj.: STiRW-CKRW, wydziały i oddziały transportu i ruchu wojsk poszczególnych struktur organizacyjnych Sił Zbrojnych, WKTr, komórki HNS oraz elementy mobilne regulacji ruchu w postaci kompanii regulacji ruchu, ŻW oraz Policji. Elementy regulacji ruchu mają za zadanie zwiększenie bezpieczeństwa w czasie przejazdów. Ważną rolę odgrywa również, prawidłowe oznaczenie pojazdów poruszających się w kolumnach wojskowych oraz oznakowanie infrastruktury drogowej. W zachowaniu bezpieczeństwa przemieszczania sił zbrojnych decydująca role odgrywają również organy kontroli (ŻW, Policja), których zadaniem jest kontrolowanie: przestrzegania przepisów ruchu drogowego, stanu trzeźwości kierujących pojazdami, stanu technicznego pojazdów, dokumentacji pojazdów i kierujących, sprawdzanie ładunków na środkach transportu. W celu zachowania bezpiecznej odległości i prędkości jazdy istotną wagę nabiera w szczególności rola kierunkowego, jadącego pierwszym pojazdem, w celu zapewnienia płynności jazdy oraz $z$ drugiej strony ważnym aspektem $w$ bezpieczeństwie przejazdów kolumn jest dyscyplina kierujących w zakresie bezpiecznej prędkości i odległości od pojazdu poprzedzającego.
Znajomość zasad i procedur przemieszczania jednostek wojsk własnych i sił zbrojnych innych państw przyczyni się do zachowania bezpieczeństwa na drogach.

\section{BIBLIOGRAFIA}

1. Zasady Wojskowego Ruchu Drogowego - DU.4.4.4 B, sygn. MON DGRSZ, Szef. Kom. 189/2015,

2. Ustawa z dnia 20 czerwca 1997 r. Prawo o ruchu drogowym (Dz. U. z 2017 r. poz. 1260, z późn. zm.),

3. Ustawa z dnia 23 września 1999 r. o zasadach pobytu wojsk obcych na terytorium Rzeczypospolitej Polskiej oraz zasadach ich przemieszczania się przez to terytorium (Dz. U. z 2016 r. poz. 1108 z póżn. zm.),

4. Ustawa z dnia 24 sierpnia 2001 r. o Żandarmerii Wojskowej i wojskowych organach porządkowych (Dz. U. z 2016 r. poz. 1483 z późn. zm.),

5. Ustawa z dnia 19 sierpnia 2011 r. o przewozie towarów niebezpiecznych (Dz. U. z 2016 r. poz. 1834 z późn. zm.),

6. Umowa Europejska o przewozie drogowym towarów niebezpiecznych - ADR (Dz. U. z 2015 r. poz. 882 z późn. zm.),

7. Rozporzadzenie Ministra Transportu, Budownictwa i Gospodarki Morskiej z dnia 23 maja 2012 r. w sprawie pilotowania pojazdów nienormatywnych,

8. Rozporządzenie Ministra Obrony Narodowej oraz Spraw Wewnętrznych i Administracji z 9 czerwca 2005 r. w sprawie warunków technicznych pojazdów specjalnych i pojazdów używanych do celów specjalnych Sił Zbrojnych RP (Dz. U. z 2005 r. poz. 974),

9. Rozporządzenie Ministra Obrony Narodowej oraz Spraw Wewnętrznych i Administracji z 24 czerwca 2016 r. w sprawie warunków technicznych pojazdów specjalnych i pojazdów używanych do celów specjalnych Sił Zbrojnych RP (Dz. U. z 2016 r. poz. 1027),

10. Rozporządzenie Ministra Obrony Narodowej z dnia 9 listopada 2012 r. w sprawie warunków krajowego przewozu towarów niebezpiecznych środkami transportu należącymi do Sił Zbrojnych $R P$ lub środkami transportu, za które Siły Zbrojne $R P$ są odpowiedzialne (Dz. U. z 2012 r. poz. 1364),

11. Rozporządzenie Ministra Obrony Narodowej z dnia 11 marca 2016 r. w sprawie wydawania zezwoleń wojskowych na przejazd drogowy pojazdów przewożących towary niebezpieczne (Dz. U. Z 2016 r. poz. 362),

12. Rozporządzenie Ministra Spraw Wewnętrznych i Administracji z dnia 6 lipca 2010 r. w sprawie kierowania ruchem drogowym (Dz. U. z 2016 r. poz. 143),

13. Rozporządzenie Ministra Obrony Narodowej z dnia 6 kwietnia 2017 r. w sprawie sposobu i trybu wydawania zezwoleń wojskowych na przejazd drogowy oraz sposobu organizacji i oznakowania kolumn pojazdów Sił Zbrojnych Rzeczypospolitej Polskiej (Dz. U. z 2017 r. poz. 809),

14. Rozporządzenie Ministra Obrony Narodowej z dnia 21 listopada 2012r. w sprawie sposobu i trybu wydawania zezwoleń wojskowych na przejazd drogowy oraz sposobu organizacji i oznakowania kolumn pojazdów SZRP (Dz.U poz. 1368 z dnia 6 grudnia 2012r.),

15. Rozporzadzenie Ministra Obrony Narodowej z dnia 29 sierpnia 2017 r. w sprawie kontroli ruchu drogowego i kierowania tym ruchem przez wojskowe organy porządkowe oraz warunków itrybu współdziałania Żandarmerii Wojskowej z Policja w prowadzeniu ewidencji kierowców naruszających przepisy ruchu drogowego (Dz. U. z 2017 r. poz. 1730), 
16. Decyzja Nr 352/MON z dnia 6 listopada 2012 r. w sprawie wydawania zezwoleń na przemieszczanie pojazdów Sił Zbrojnych $R P$ za granice państwa (Dz. Urz. MON z 2012 r. poz. 442).

17. Ustawa o drogach publicznych z 21.03.1985 r. (Dz.U. 2017 poz. 2222 z późn. zm.).

18. Raport Krajowej Rady Bezpieczeństwa Ruchu Drogowego w zakresie stanu bezpieczeństwa ruchu drogowego oraz działań realizowanych w tym zakresie w 2015 roku, www.kbrrd.gov.pl

19. Statystyki Komendy Głównej Policji, www.statystyka.policja.pl.

20. www.defence24.pl.

21. www.army.mil.pl

22. www.zw.wp.mil.pl

23. www.federal.pl
24. www.info-car.pl

25. www.gddkia.gov.pl

Autorzy:

mgr inż. Wojciech Puszkiewicz - Państwowa Wyższa Szkoła Zawodowa w Pile, Instytut Politechniczny, Zakład Transportu.

dr hab. inż. Piotr Piątkowski, prof. PK, prodziekan ds. Studenckich - Politechnika Koszalińska, Zakład Transportu, Wydział Mechaniczny.

JEL: L99 DOI: 10.24136/atest.2018.237

Data zgłoszenia: 2018.05.28 Data akceptacji: 2018.06.15 